\title{
CONTROL OF AN INTEGRATED COMPANY'S WOOD SUPPLY ${ }^{1}$
}

\author{
By K. G. BOYD ${ }^{2}$
}

The handling of a major integrated company's wood raw material supply on the B.C. Coast falls into three major fields of activity. Each of these must be closely correlated with the others as well as the company's logging. converting, and sales departments.

The three fields of activity are:

PLANNING

PURCHASING AND SALES

ALLOCATION AND CONTROL

\section{Long Term}

PlanNing

This phase is the key to major expansions, timber acquisitions, and long term supply contracts for logs or chips. The assured sources of supply from Tree Farm Licences, Tree Farms and other company holdings are projected ahead on calculated allowable cuts as a base. Added to this are estimated open market log and chip purchases. This supply is then allocated by type to existing converting units and the resulting supply picture, including byproduct chips and hog fuel, establishes a base plan. This plan can be adjusted to reflect projected increased wood supply and converting capacity, or changes in plants to use the type of wood available in the future and serve forecast markets.

\begin{abstract}
Annual Plans
The annual Wood Supply and Consumption Plan is based on current allowable cuts and present plant capacities. The preliminary plan is generally completed in early September using tentative lumber, plywood, pulp and newsprint sales forecasts with logging plans tied to normal development in each operation. Log purchases at this stage reflect expected normal open market supply and trade relationships.

This preliminary plan is then refined to meet firmer sales plans through changes in consumption, logging and log purchasing plans. In MacMillan, Bloedel and Powell River Limited this involves the production of 18 logging operations with $1,200 \mathrm{MM}$ board feet of logs, 12 converting units producing shingles, lumber, plywood, pulp, paper and newsprint plus a $\log$ and chip purchasing and sales program involving $550 \mathrm{MM}$ board feet annually.

${ }^{2}$ Based on part of a talk given at the January, 1965 meeting of the Vancouver Section of C.I.F.

Manager, Log Supply Division, MacMillan, Bloedel and Powell River Limited, Vancouver, B.C.
\end{abstract}


Some $18 \log$ types are allocated to the various mills in this plan.

The normal recognized types are:

$$
\begin{aligned}
& \text { Fir } \\
& \text { - No. } 1 \& 2 \text { Peelers } \\
& \text { No. } 3 / 4 / 5 \text { Peelers } \\
& \text { - Sawlogs } \\
& \text { - Pulp } \\
& \text { Hemlock/Balsam - Balsam Peelers } \\
& \text { - Clear Hemlock } \\
& \text { - Sawlogs } \\
& \text { - Pulp } \\
& \begin{array}{cl}
\text { Cedar } & \text { - Siding } \\
& \text { - Shingle } \\
& \text { - Merch. } \\
& \text { - Pulp } \\
\text { Spruce } & \text { - Peeler } \\
& \text { - Clear } \\
& \text { - Merch. } \\
\text { - Pulp } \\
\text { Pine } & \text { - Sawlog } \\
\text { Cypress } & \text { - Sawlog }
\end{array}
\end{aligned}
$$

These are sometimes further sub-divided at the operating level into categories such as gang and standard sawlogs or diameter classifications to balance sawmill headrigs or pulpmill woodrooms. Salvage wood, thinnings, etc., are also generally shown separately. This plan becomes the base for the company's production, sales and profit plan for the year.

\section{Short Term}

Four-month forecasts are prepared each month to maintain a running control of supply and usage. Actual performance in each area is checked monthly and adjustments made to the annual plan as differences arise. This is largely a control function.

\section{Special Studies}

These are continuous and involve such things as chip recovery, log size studies and forecasts, changes in sorts, and re-allocations, etc.

Logs

\section{PURCHASING AND SALES}

The purchasing and sales section have the major responsibility of acquiring $16-18 \%$ of our net log volume. In addition, they are required to sell and trade off species and types that are surplus to our requirements or are not used at all by our mills. The function is therefore two fold - to acquire additional logs and to balance the requirements by types. This results in $25-26 \%$ of the logs used in our plants being acquired through purchasing.

The B.C. Coast Log Market was highly competitive through 1964 with price increases of $20 \%$ on some species. For example, the average price of hemlock and cedar logs rose from approximately $\$ 50.00$ to $\$ 60.00$ per M board feet B.C. Log Scale by the end of 1964.

The open market logger who is committed to no consumer normally sells through one of the log brokers established in Vancouver. These brokers provide a number of services to the logger including marketing, invoicing, acting as an intermediary in financing, accounting and business advice. It is in this free and open market that log prices are established which dictate the prices paid on inter-company trading and for chips. 
Inter-company trading is an important part of the log flow on the Coast. Companies with their own log supply and converting facilities trade off surpluses and types they don't use for types they require. This business, which each company carries out to balance its supply and consumption is carried out at the market prices prevailing when the logs are delivered. MacMillan, Bloedel \& Powell River Limited purchases some 400 MM FBM of logs annually and sells $150 \mathrm{MM}$. About $50 \%$ of the logs sold are produced in our own camps, the remainder are logs purchased and resold on trade for other types. In some instances trades of the same types are made to reduce transportation costs or to solve short term shortages.

Logs are normally purchased on a boom-to-boom basis. The log buyer, sometimes in company with the seller, inspects the logs offered at camp or somewhere en route to market. During this inspection he notes such things as average diameter and length, decay, teredo or insect damage, and general quality, including twist, sweep, roughness, and grain. Following this inspection the buyer will offer a price per M FBM by grade based on his knowledge of the current market and the end use to which his company will put the logs. These deals, often involving $\$ 100,000$ or more, are made and honored verbally throughout the industry. Log prices are quoted in terms of sorted booms delivered to the Vancouver Market, which is generally considered to be Howe Sound, a major storage and marshalling area just outside Vancouver. Logs sold at points other than the Vancouver Market generally command a lower price due to the lower cost of delivery and other factors.

\section{Chips and Hog Fuel}

The by-product chip production on the B.C. Coast in 1964 equalled 3.1 MM volume units or approximately $220 \mathrm{MM}$ cubic feet of solid wood. Of this volume, which excludes chips manufactured in pulp mill woodrooms, $65 \%$ were produced from waste in integrated companies' own sawmills, shingle mills and plywood plants. The other $35 \%$ or $75 \mathrm{MM}$ cubic feet came from mills producing from 5,000 to 125,000 units annually. Wood chips exported to the U.S.A. accounted for $17 \%$ of the 1964 production, a decrease of $6.5 \%$ from 1963.

By-product chip recovery varies greatly with equipment and log type but a general guide is:

$\begin{array}{llll}\text { - Sawmills } & 1.0 \text { Unit/ M FBM Logs } \\ \text { - Plywood } & 0.8 " & " & " \\ \text { - Shingle } & 0.5 " & "\end{array}$

Only the smallest mills are not equipped with barkers and chippers and some of these pick clean wood for sale to other mills or one of the few small chipping plants in the area.

By-Product chip prices on the Coast are based on the going open market price of No. 3 Hemlock logs. Current (March, 1965) price of these logs is $\$ 58.50 / \mathrm{M}$ FBM and chip prices f.o.b. scow at the supplying mill are expressed as a percentage of this price -
i.e. $\mathrm{Hem}$
Fir
$35-37 \%$
$25-30 \%$
$18-20 \%$ 
At these prices Hemlock/Balsam chips with transportation added will cost $\$ 0.33$ - $\$ 0.35$ per cubic foot of solid wood at the pulp mill. This is high cost wood.

The sale and purchase of chips is chiefly under 3-5 year contracts with a set percentage as above for the period. In some instances the longer contracts contain price revision clauses effective at the end of 2 or 3 years.

As the pulpmills on the B.C. Coast are all situated between 30 and 200 miles from the main sawmilling centre in the lower Fraser River and Vancouver, most chips are moved by scows that carry from 500 - 900 units each. In addition to the chips produced on the Coast there has been a steady volume brought in by rail from the Interior and transferred to scows for delivery to the pulp mills. This supply, some of it railed up to 500 miles, is expected to be absorbed over the next few years by pulp mills being constructed or planned in the Interior.

The scheduling of several hundred thousand units of chips annually from a number of sawmills and plywood plants to one or more pulp mills is an important part of an integrated company's supply problem.

Hog fuel, the bark, sawdust and other waste that escapes the chipper, has become a marketable product as pulpmills have expanded and purchase it as fuel. A pulpmill's boiler installation cost is higher to enable it to use hog fuel but it solves a disposal problem for the large integrated companies and does offer some savings over oil on current prices.

The prevailing prices f.o.b. scow in this area are:

$$
\begin{array}{ll}
\text { - Hemlock/Balsam } & \$ 0.20 / \text { Unit } \\
\text { - Fir } & 0.50 / \text { Unit } \\
\text { - Cedar } & \text { Nil }
\end{array}
$$

This market has practically eliminated the waste burner on the Coast.

\section{Log Allocation}

This function covers all the details involved in getting each $\log$ to the right end use. This will be discussed under five headings.

\section{Sorting and Allocation}

Most of the logs produced on the Coast are dumped into the water and towed in booms or barged to market. Sorting into separate booms by species and type is done in the water either at the dumping point or at a sorting grounds near the market. Up to 20 sorts are made by the larger companies to supply each of the various mills with the best diet of logs related to their equipment and end product. The checking of this sorting and the issuance of new instructions as conditions and demands change is a constant function in a large integrated company.

Booms purchased on the open market are assigned a recommended specific mill allocation when inspected by the buyer. This is later either confirmed or changed by the Allocation Section.

\section{Transportation}

Log transportation on the B.C. Coast from logging operation to mill is chiefly by water in booms or on log barges. Flat booms are made up in sections, each of which are $66^{\prime}$ long and $66^{\prime}$ wide containing from 15 M FLS 
(fbm log scale) to $40 \mathrm{M}$ FLS depending on log size and quality. These booms, generally of 4,6 or 8 sections contain single logs surrounded by $66^{\prime}$ boomsticks and cross-linked at the end of each stick by a $66^{\prime}$ swifter log which holds the boom together and the logs in place. The swifters and boomsticks are joined together with $1^{\prime \prime}$ chains about $9^{\prime}$ long.

Bundle booms are basically the same but the logs are in bundles and the swifter $\log$ is often replaced by a 1 and $1 / 8^{\prime \prime}$ galvanized wire rope line. Bundle booms have the advantage of containing more volume per section (40 - $65 \mathrm{M}$ FLS), and of standing up better in rough water.

The result is lower log losses and lower towing rates; savings can be as much as $25 \%$. Bundles vary in size from $5 \mathrm{M}$ FLS to $15 \mathrm{M}$ FLS depending on the method used. The smaller bundles of $5-8 \mathrm{M}$ FLS are generally dumped loose, sorted at the camp, scaled and then bundled in the water. The larger bundles are full truck loads that are towed to a central area for sorting and scaling. The bundles are held together by either one or two $5 / 8$ " wire rope straps with a special clamp, or flat steel bands; the former is in most general use by major producers. Both flat and bundle booms are used in the relatively protected waters of the Gulf of Georgia and the main Inlets.

Log barging has become increasingly important as log sources outside the protected water areas are opened up. These barges carry from 500 M FLS to $2,000 \mathrm{M}$ FLS and are towed by tugs in the 1,200 to 2,500 horsepower range. Some are flat decks loaded at the source by a stationary loading works, while others have cranes mounted on the barge and load themselves. All are self-dumping through introducing water into one side to tip the barge and let the load slide off.

The transportation business is carried out by independent or subsidiary towing companies on contract with rates per M FLS set according to locality, distance, size of tows, and volume per section. The job of the allocation people in this field is to keep all the logs moving toward their proper destination in the most direct route and in the largest possible packages.

\section{Scaling}

B.C. has two official scales, the B.C. Log Scale and the B.C. Cubic Scale. The latter is mandatory on all timber in which the Crown claims an equity, but on the Coast of B.C. all business, except minor (to date) volumes of salvage, is carried out on the board foot B.C. Log Scale.

Most companies have their own scaling staff to check on the official scale of booms bought and sold. Rescales can be called and if the original was out more than $2 \%$ a new scale bill will be issued by the Government whose scaling staff does all the official scaling.

In addition, the company scalers mark logs for sorting, inspect booms for purchase or sale, and carry out special studies. There are also a number of independent scaling companies that do this type of work on a daily basis for firms that don't have their own scalers, or require additional help.

\section{Log Losses}

The towing and storage of logs in flat booms inevitably results in log 
losses. Tows may be broken up by waves or forced ashore by wind and tide if the tow is caught by an unforecasted storm. When this happens, we have to arrange maximum recovery as quickly as possible to salvage the logs before they are spread for miles along the Coast. Licensed beachcomb boats are called out to salvage the spilled logs and move them to safe storage for rebooming. The price paid for this operation is negotiated between the owners and the beachcombers. The rate varies with distances, weather, log size, etc.

A unique organization, the Gulf Log Salvage Co-operative Assn., is organized to receive beachcombed logs on behalf of the owners in the Gulf of Georgia area. The share of the $\log$ value paid to the beachcomber, the Crown, the Association, and the Owners is set by law.

\section{Inventory Control}

With a somewhat seasonal flow of logs in volume as well as by type, an inventory readily available to the mills and in the pipeline must be kept in balance. As the first three months of the year is normally the worst logging period, a desired inventory level for December 31st is generally established. Depending on an individual company's ability to produce logs under winter conditions this inventory is set at from three to four months supply for each converting plant.

On a regular operating basis log inventories are handled as much as possible on a "first in, first out" procedure to minimize losses from sinkage and teredine borers. This ideal rotation of inventory is often frustrated by special production or sales requirements at the mills. 